\title{
Comparative Study of Solar Inactivation of Total Coliforms through Transparent Plastic Bottles and Fabricated Disinfection Setup
}

\author{
KUNDAN KUMAR*, MARYAM ARAIN*, AND AZIZULLAH CHANNA* \\ RECEIVED ON 03.05.2018 ACCEPTED ON 17.08.2018 \\ ABSTRACT
}

\begin{abstract}
The water is disinfected through different techniques commonly used at domestic level, including boiling, chlorination, UV (Ultraviolet) disinfection, etc. These methods require extensive amount of chemicals, energy and trained manpower. The solar disinfection of drinking water found as best among all other disinfection techniques as it is easy to apply, economically feasible and environmentally friendly technique. In this study a series of experiments were conducted in order to characterize the bacterial inactivation process contained in FDS (Fabricated Disinfection Setup), consists of a stainless steel tub and glass covering, and TPB (Transparent Plastic Bottles). In this study the role of solar radiation in bacterial inactivation process is compared in transparent plastic bottles and stainless steel tub to determine the performance of both by simulating conditions of turbidity, temperature, and exposure time. The results showed that disinfection of water contained in a stainless steel tub promoted more successful inactivation of total Coliforms reduction about $80 \%$ than that of transparent plastic bottles about $70 \%$.
\end{abstract}

Key Words: Bacterial Inactivation, Disinfection, Solar Radiation, Total Coliform.

\section{INTRODUCTION}

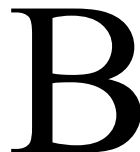

acterial inactivation of water can be achieved through different physical and chemical methods such as by UV radiation and by applying $\mathrm{H}_{2} \mathrm{O}_{2}$ [1]. Wastewater can also be treated by using solar radiation and can be reuse for irrigating agriculture and the treatment efficiency of solar inactivation was comparable to traditional wastewater treatment methods [2].

Until now the disinfection of water is majorly based on chlorination due to their oxidizing character, availability, economics and ability to remove pathogens. But due to growing concern for the formation of trihalomethane a dangerous substance for human health alternative methods can be used for alleviating the carcinogenic effect of trihalomethane. Advanced oxidation process e.g. heterogeneous Fenton was also evaluated for inactivating total coliform and E.coli [3-6].

Solar bacterial inactivation is process of making water free from biological contamination and to make it safe for drinking purpose.

Authors E-Mail: (ms.maryam@faculty.muet.edu.pk, kundan_200693@yahoo.com, azizullah.channa@faculty.muet.edu.pk) *Institute of Environmental Engineering \& Management, Mehran University of Engineering \& Technology, Jamshoro, Pakistan.

This is an open access article published by Mehran University Research Journal of Engineering and Technology, Jamshoro under the CC by 4.0 International License. 
Polluted portable water contains a major health issues to living beings globally. The issue is distinctly notable in underdeveloped nations mostly in dry regions of the world where water sources are insufficient. In developing nations, ground water resources such as rivers, streams and lakes are used for different purposes, inclusive of animal watering, bathing, drinking, and cooking. The discharge of feces from the body and urination mostly occur near water origins; like abstraction wells and other water bodies [7]. Such drinking water sources become contaminated with pathogenic organisms due to the waste of human and animal excreta. Individuals in underdeveloped nations might not have other choice for drinking water, due to the scarcity of water, lack of water treatment plants and the environmental conditions of the area $[8]$.

More than one billion individuals every year are getting into contact to unprotected potable water because of bad source impure water quality and lack of satisfactory water treatment [9]. This outcome in 9x108 cases of diarrhea every year. 5 out of every 1000 of those exposed to unprotected drinking water will lose their life due to harmful diseases carried by the polluted water; 2.5 will lose their life from dehydration due to diarrhea mostly children are affected. Diarrheal infection results in undernutrition, fatigue, and an increase in susceptibility to diseases, and can be life harming. Approximately 2.5-15 million number of children pass away every year because of water borne and related diseases [10].

The lack of satisfactory drinking water in underdeveloped nations is a constantly increasing issue; due to rapid increase in mankind which has adverse impact on the drinking water sources. Demand of water for growing population, industry and the other recreational uses is a challenge for the developing world. Polluted water sources must be treated properly for the drinking purpose. The major water pollutants are known as pathogens (diseases causing) bacteria, physical and chemical substances, amongst these pollutants pathogenic bacteria are more harmful to health [11]. For the treatment/removal of pathogenic microorganisms/bacteria various methods are employed during the drinking water treatment [12]. Countryside communities dependent on boiling as a disinfectant, normally consume one $\mathrm{kg}$ of wood fire for every litre of water, which is outside the income of utmost family unit [13]. Only the water disinfection through the solar radiations is known as cheapest method of water treatment. Whereas water is exposed to the sun light for the specific time to destroy the bacteria through solar radiations. Besides this no special technology, or manpower is required to run the system which makes it environment friendly, economical, and easy to apply for the production of disinfected water for the drinking and cooking purpose for the members of a household family [14].

The maximum advantage of this system is recommended for the areas which get maximum solar radiation, especially (areas) between the latitude of $35^{\circ} \mathrm{C}$ to the North and South [15]. Some variables those effect on the system are also reported during the previous studies conducted on the solar disinfection. These variables involve the intensity of solar radiation, air and water temperature, turbidity, amount of microorganisms and the vessel material and transparency. The inactivation of pathogenic organisms including the thermo tolerant bacteria are reported at the temperatures of water from $40-60^{\circ} \mathrm{C}[16]$.

From the literature it was conceived that the previous studies work was carried out to characterize the bacterial 
inactivation contained in transparent plastic in bottles and different container were separately studied but present study has a focus on comparison of efficiencies of plastic bottles and stainless steel tub. Furthermore, a new equipment was designed and its efficiency was compared with already systems available in the literature. This study was also conducted to find out the best disinfection method by determining the effects of temperature, exposure time and turbidity on both setups. This present study was carried out to explore the potential of this inexpensive disinfection technology by comparing the bacterial inactivation process in transparent plastic bottles and fabricated disinfection setup.

\section{METHODOLOGY}

The impacts of sun radiation on the inactivation of total Coliforms were tested from July to September 2017. Water sample were kept in sunlight in transparent plastic bottles and fabricated disinfection setup consist of stainless steel tub with glass covering the top. For each experiment, the water samples were prepared in the testing laboratory.

(1) The efficiency of solar disinfection in transparent plastic bottles and fabricated disinfection setup is compared by considering these parameters as shown in Table 1 [17].
(2) Each variable of the test was calculated for the effectiveness of the solar radiation for the disinfection of the bacteria in fabricated disinfection setup and transparent plastic bottles.

(3) The experiment for the achievement of the objective was performed through standard methods of the microbiological water analysis, such as Membrane Filtration Technique test for bacteria [18].

(4) The results of the experiments was interpreted according to the variable where the performance of the solar radiations over the variable was calculated and recommended for potable purpose.

\subsection{Preparation of Sample Water}

The water sample used in the test were prepared by contaminating distilled water with coliform bacteria and desired turbidity were obtained by mixing Kaolin solution in each sample. Kaolin solution was prepared, by adding five grams of laboratory grade kaolin (Anachemia AC5302 ) into a liter of water. About $1000 \mathrm{ml}$ of kaolin solution was added to 20 liters to get the desired turbidity of 250

TABLE 1. PARAMETERS AFFECTING SOLAR DISINFECTION

\begin{tabular}{|c|r|r|}
\hline No. & Parameters & Description \\
\hline 1. & Turbidity (NTU) & Unclearness is water, it decreases removal \\
\hline 2. & Total Coliform Count (CFU) & Indicator microorganisms found in water. Mostly these show the presence of \\
pathogenic organism.
\end{tabular}

Mehran University Research Journal of Engineering \& Technology, Volume 38, No. 2, April, 2019 [p-ISSN: 0254-7821, e-ISSN: 2413-7219] 
NTU in the sample [19-20]. For other samples with less turbidity desired, accordingly kaolin solution was added. The level of turbidity greatly affects the solar inactivation process, a range of 0-300 have been tested [21]. That is why we have selected theses ranges. Prepared samples were exposed to sunlight for 5 hours at temperature 30 $55^{\circ} \mathrm{C}$.

The total coliform count was measured by using standard method of microbiological examination, Membrane filtration technique [22-24].

\subsection{Analysis of Raw Water and Treated Water Contained in Transparent Plastic Bottle}

The transparent plastic bottles used for the inactivation process are easily available in the market, but the life time of the bottles is very low if they are continuously used for the treatment. On the other hand, they have low cost. Different sizes of the bottles are used for the treatment as shown in Fig. 1.

Eight samples were stored in transparent plastic bottle with variable volume, turbidity and number of colonies and exposure time for all the samples was kept 5 hours.
Another one sample was stored in plastic bottle with variable exposure time, but the volume, turbidity and number of colonies were kept constant as 10 litres, 50 NTU and 240 CFU respectively.

\subsection{Analysis of Raw Water and Treated Water Contained in Fabricated Disinfection Setup}

The fabricated disinfection setup is made of stainless steel with glass top. The setup is used for the disinfection of water through solar radiation. It is 12 -inch-wide in width, 24-inch-wide in length and 6-inch-wide in height. The glass top is $4 \mathrm{~mm}$ thinner, 11 -inch-wide in width and 24-inch-wide in length. It also contains one steel nozzle and one valve as shown in Fig. 2. The capacity of the tub is 5 liter/inch. The purpose of using a stainless steel material for the setup that it would not get corrosive due to continuous storage of water sample. They life time of the fabricated setup is very long of about 10-20 years if used continuously and cost of the setup is also very low of about PKRS.2000/=.

Eight samples were placed in fabricated disinfection setup on different days with varying the depth of sample, turbidity and no: of colonies and exposure time for all the samples was kept 5 hours.

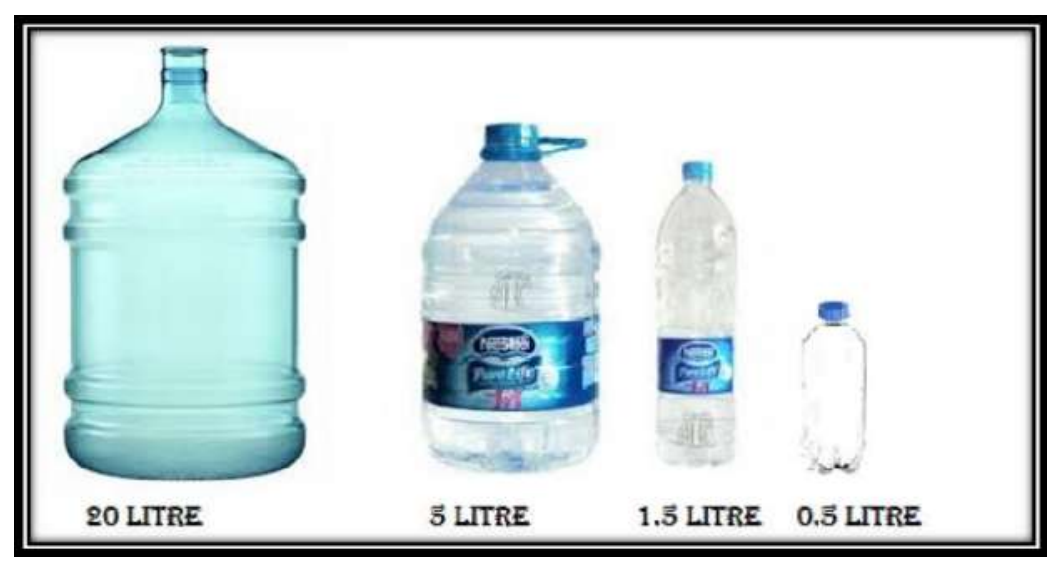

FIG. 1. TRANSPARENT PLASTIC BOTTLE 
Another one sample was stored in fabricated disinfection setup at various exposure time, but the depth, turbidity and no: of colonies were kept constant as 2 inch, 50 NTU and 240 CFU respectively.

\subsection{Testing Procedure}

\subsubsection{Membrane Filtration Technique}

To test drinking water using membrane filtration technique, a $100 \mathrm{ml}$ sample is tested. Overall coliform bacteria from filter paper with EMB agar medium are determined by using incubator at a temperature of $35 \pm$ 0.5 centigrade for 24 hours.

\section{RESULTS AND DISCUSSION}

The results were obtained at variable turbidity, volume, depth of water and exposure time. The transparent plastic bottle and fabricated disinfection setup were used to expose the contaminated water to the sun light. Following temperature conditions were observed:

- $\quad$ Air temperature $=35-48^{\circ} \mathrm{C}$

- Initial Water Temperature $=30^{\circ} \mathrm{C}$

- $\quad$ Final Water Temperature $=45-60^{\circ} \mathrm{C}$

\subsection{Comparative Representation of Percentage Reduction in FDS and TPB on the Basis of Depth/Volume of Sample}

Eight samples were placed in both the apparatus provided different removal efficiency with the change in volume or depth of the sample but the exposure time was same for all the sample as 5 hours. With the depth of 4 inch and 20 litres of volume in FDS and TPB respectively, the bacterial colonies removal percentage obtained was 8.3 and $7.3 \%$ respectively. Similarly at various different depth of 3.5, 3, 2.5, 2, 1.5, 1 and 0.5 in FDS and volume of 17, 15, 12, 10, 7, 5 and 2 in TPB, the removal percentage obtained was $10.9,17.7,29.2,35.4,47.6,73.8,80.0 \%$ and $9.5,15.1,24$, $33.3,42.2,57.1$, and $70 \%$ respectively as shown in Table 2 and Fig. 3.

\subsection{Comparative Representation of Percentage Reduction in FDS and TPB on the Basis of Turbidity}

Other eight (8) samples were placed in both the apparatus provided different removal efficiency with the change turbidity of the sample but the exposure time was same for all the sample as 5 hours. With the turbidity of 250

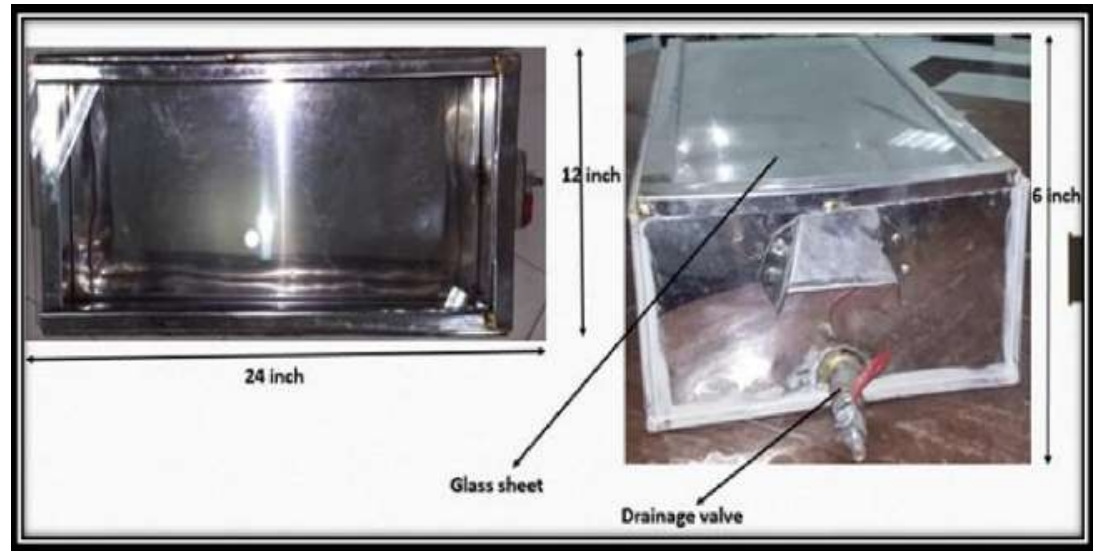

FIG. 2. FABRICATED DISINFECTION SETUP 
NTU in FDS and TPB, the bacterial colonies removal percentage obtained was 8.3 and $7.3 \%$ respectively. Similarly at various turbidity of $150,120,70,50,25,5$, and 2 NTU in FDS and TPB, the removal percentage obtained was $10.9,17.7,29.2,35.4,47.6,73.8$ and $80.0 \%$ and 9.5 , $15.1,24,33.3,42.2,57.1$ and $70 \%$ respectively as shown in Table 3 and Fig. 4.

\subsection{Comparative Representation of Percentage Reduction in FDS and TPB on the Basisof Exposure Time}

In last stage of analysis one samples was placed in both the apparatus provided different removal efficiency with the change in the exposure time but the turbidity and volume/depth of the sample were kept constant as 50NTU and 10 litre/2inches. With the exposure time of 2 hours in FDS and TPB , the bacterial colonies removal percentage obtained was 20.8 and $12.5 \%$ respectively. Similarly at various exposure time of 4,6,8 and 10 hour in FDS and TPB, the removal percentage obtained was 33.3,43.3,58.3 and $70.8 \%$ and $20.8,35.4,50$ and $62.5 \%$ respectively as shown in Table 4 and Fig. 5

By performing experiments on above conditions we did not find better results of percent reduction in the colonies forming bacteria in the samples having turbidity 250 NTU. Therefore, if the turbidity of water is greater

TABLE 2. PERCENTAGE REDUCTION IN BACTERIA BY VARIATION IN DEPTH/VOLUME OF SAMPLE CONTAINED IN (FDS) AND (TPB)

\begin{tabular}{|c|c|c|c|c|c|c|c|c|}
\hline No. & $\begin{array}{c}\text { Depth of } \\
\text { Sample in FDS } \\
\text { (inch) }\end{array}$ & $\begin{array}{c}\text { Volume of } \\
\text { Sample in TPB } \\
\text { (litre) }\end{array}$ & $\begin{array}{c}\text { Exposure Time } \\
\text { (hour) }\end{array}$ & $\begin{array}{c}\text { Before } \\
\text { Disinfection } \\
\text { Number of } \\
\text { Colonies/100- } \\
\mathrm{ml}\end{array}$ & \begin{tabular}{c}
\multicolumn{1}{c}{ After } \\
Disinfection \\
Number of \\
Colonies in \\
FDS/100ml
\end{tabular} & $\begin{array}{c}\text { After } \\
\text { Disinfection } \\
\text { Number of } \\
\text { Colonies in } \\
\text { TPB/100ml } \\
\end{array}$ & $\begin{array}{l}\text { Reduction in } \\
\text { FDS } \\
(\%)\end{array}$ & $\begin{array}{c}\text { Reduction in } \\
\text { TPB } \\
(\%)\end{array}$ \\
\hline 1 & 4 & 20 & \multirow{8}{*}{5} & 300 & 275 & 278 & 8.3 & 7.3 \\
\hline 2 & 3.5 & 17 & & 285 & 254 & 258 & 10.9 & 9.5 \\
\hline 3 & 3 & 15 & & 265 & 218 & 225 & 17.7 & 15.1 \\
\hline 4 & 2.5 & 12 & & 250 & 177 & 190 & 29.2 & 24.0 \\
\hline 5 & 2 & 10 & & 240 & 155 & 160 & 35.4 & 33.3 \\
\hline 6 & 1.5 & 7 & & 225 & 118 & 130 & 47.6 & 42.2 \\
\hline 7 & 1 & 5 & & 210 & 55 & 90 & 73.8 & 57.1 \\
\hline 8 & 0.5 & 2 & & 200 & 40 & 60 & 80.0 & 70.0 \\
\hline
\end{tabular}

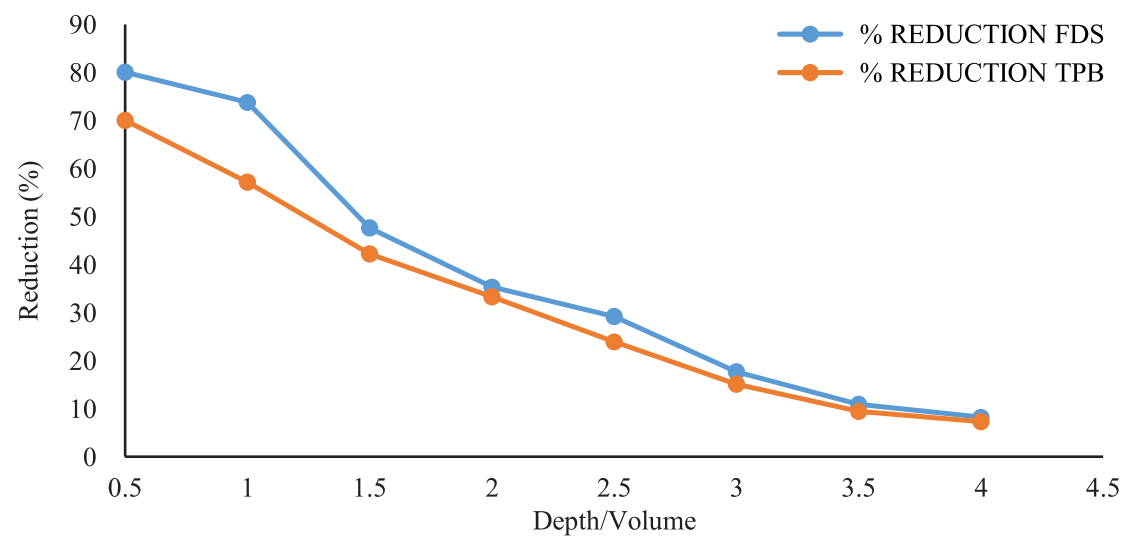

FIG. 3. DEPTH/VOLUME VS \% REDUCTION 
than $20 \mathrm{NTU}$, the water needs to be pre-treated before being exposed. Larger constituent part and solid objects can be removed by keeping the untreated water for a single day and allowing the constituent part to settle down to the lowermost area [25-27]. Turbidity concentration can also be decreased by flocculation/ sedimentation by means of Aluminium Sulphates or Moringa oleifera seeds [28].

\section{TABLE 3. PERCENTAGE REDUCTION IN BACTERIA BY VARIATION IN TURBIDITY OF SAMPLE CONTAINED IN} FDS AND TPB

\begin{tabular}{|c|c|c|c|c|c|c|c|}
\hline No. & $\begin{array}{c}\text { Turbidity in FDS } \\
\text { and TPB }\end{array}$ & (NTU) & $\begin{array}{l}\text { Exposure Time } \\
\text { (hour) }\end{array}$ & $\begin{array}{c}\text { Before } \\
\text { Disinfection } \\
\text { Number of } \\
\text { Colonies } / 100 \mathrm{ml} \\
\end{array}$ & $\begin{array}{c}\text { After Disinfection } \\
\text { Number of } \\
\text { Colonies in } \\
\text { FDS } / 100 \mathrm{ml} \\
\end{array}$ & $\begin{array}{l}\text { After Disinfection } \\
\text { Number of } \\
\text { Colonies in } \\
\text { TPB/100ml } \\
\end{array}$ & $\begin{array}{l}\text { Reduction in } \\
\text { FDS (\%) }\end{array}$ \\
\hline 1 & 250 & \multirow{8}{*}{5} & 300 & 275 & 278 & 8.3 & 7.3 \\
\hline 2 & 150 & & 285 & 254 & 258 & 10.9 & 9.5 \\
\hline 3 & 120 & & 265 & 218 & 225 & 17.7 & 15.1 \\
\hline 4 & 70 & & 250 & 177 & 190 & 29.2 & 24.0 \\
\hline 5 & 50 & & 240 & 155 & 160 & 35.4 & 33.3 \\
\hline 6 & 25 & & 225 & 118 & 130 & 47.6 & 42.2 \\
\hline 7 & 5 & & 210 & 55 & 90 & 73.8 & 57.1 \\
\hline 8 & 2 & & 200 & 40 & 60 & 80.0 & 70.0 \\
\hline
\end{tabular}

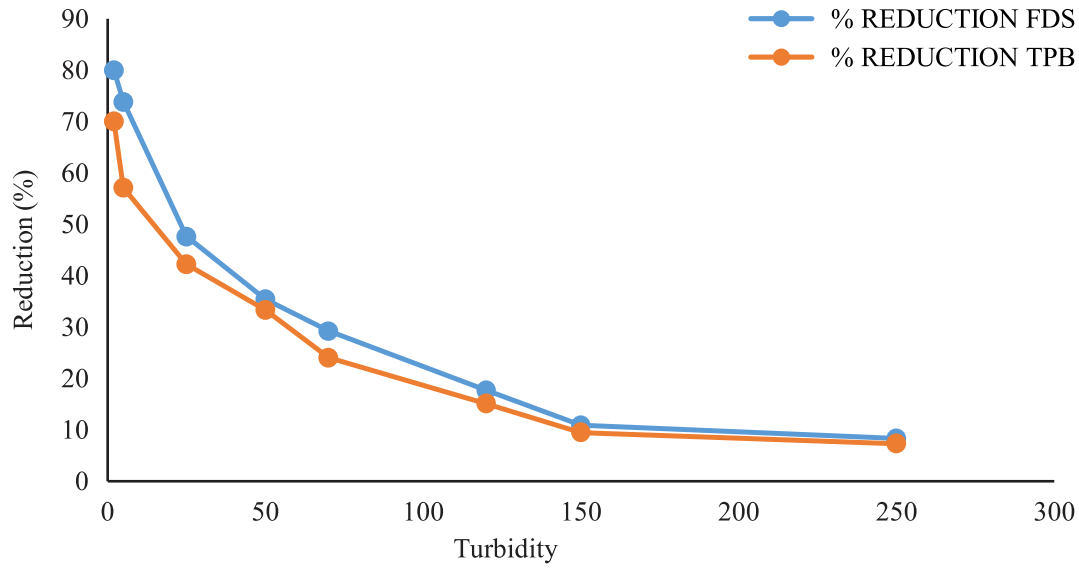

FIG. 4. TURBIDITY VS \% REDUCTION IN BACTERIA

TABLE 4. PERCENTAGE REDUCTION IN BACTERIA BY VARIATION IN EXPOSURE TIME OF SAMPLE CONTAINED IN FBS AND TPB

\begin{tabular}{|c|c|c|c|c|c|c|c|c|c|}
\hline No. & $\begin{array}{c}\text { Depth of } \\
\text { Sample in } \\
\text { FDS (inch) }\end{array}$ & $\begin{array}{l}\text { Volume of } \\
\text { Sample in } \\
\text { TPB (litre) }\end{array}$ & $\begin{array}{l}\text { Turbidity in } \\
\text { FDS and } \\
\text { TPB (NTU) }\end{array}$ & $\begin{array}{c}\text { Exposure } \\
\text { Time (hour) }\end{array}$ & $\begin{array}{c}\text { Before } \\
\text { Disinfection in } \\
\text { FDS and } \\
\text { TPB } \\
\text { Number of } \\
\text { Colonies/ } \\
100 \mathrm{ml}\end{array}$ & $\begin{array}{c}\text { After } \\
\text { Disinfection } \\
\text { Number of } \\
\text { Colonies in } \\
\text { FDS/100ml }\end{array}$ & $\begin{array}{c}\text { After } \\
\text { Disinfection } \\
\text { Number of } \\
\text { Colonies in } \\
\text { TPB/100ml }\end{array}$ & $\begin{array}{c}\text { Reduction in } \\
\text { FDS } \\
(\%)\end{array}$ & $\begin{array}{c}\text { Reduction in } \\
\text { TPB } \\
(\%)\end{array}$ \\
\hline 1 & \multirow{5}{*}{2} & \multirow{5}{*}{10} & \multirow{5}{*}{50} & 2 & \multirow{5}{*}{240} & 190 & 210 & 20.8 & 12.5 \\
\hline 2 & & & & 4 & & 160 & 190 & 33.3 & 20.8 \\
\hline 3 & & & & 6 & & 135 & 155 & 43.8 & 35.4 \\
\hline 4 & & & & 8 & & 100 & 120 & 58.3 & 50.0 \\
\hline 5 & & & & 10 & & 70 & 90 & 70.8 & 62.5 \\
\hline
\end{tabular}

Mehran University Research Journal of Engineering \& Technology, Volume 38, No. 2, April, 2019 [p-ISSN: 0254-7821, e-ISSN: 2413-7219] 


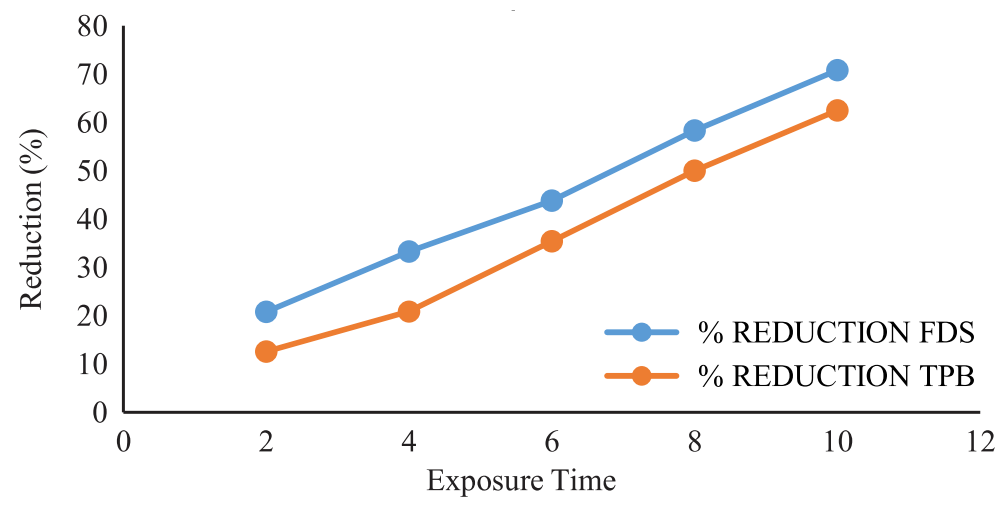

FIG. 5. EXPOSURE TIME VS \% REDUCTION

\section{CONCLUSION}

The purpose of doing this study is to determine the disinfection of water by using the natural energy and the purpose of building up this simple apparatus is to disinfect the water in proper way and to provide the rural areas a good quality of apparatus in cheap and low maintenance cost. This is a simple method of disinfecting water in which we can vary the turbidity, depth or volume of sample, time of exposure, temperature. It is a user friendly interface experiment setup. The solar water disinfection method is much easier than other methods. With the help of solar water disinfection apparatus, we can determine the variation in the CFU through concentration of solar radiation.

Solar water disinfection is an investigation method where optimum conditions are determined. The values we obtain over the experiments are correlated and adjusted in order to account for adjusting the parameter required for disinfection.

(i) It is very difficult to conclude this study on the basis of simple parameters of water quality as the turbidity and bacteria (CFU). For this study sampling and analysis were conducted during the hot season of the year in the month of July to September. Whereas the air temperature were recorded $35-48^{\circ} \mathrm{C}$.

(ii) The solar disinfection efficiency at the work place was accepted the maximum temperature favourable for the water disinfection. The result and conditions may not be favourable during the winter seasons or cold months of the years.

(iii) The study proved that greater bacterial log inactivation was obtained on water samples in fabricated disinfection setup having a water depth of 1 inch compared to water samples having 4-inch depth. Likewise, greater bacterial $\log$ inactivation was obtained on water samples in transparent plastic bottles having water volume of 02 litres compared to water samples of 20 liters. This might be because of the decrease in penetration of solar radiation with increasing water depth.

(iv) The disinfection is feasible with this method, but majorly depend on the location of the treatment. The reduction of bacterial counts obtained from the experiment are enough for water used for the daily use purpose except for drinking purpose. 


\section{ACKNOWLEDGEMENT}

Authors would like to acknowledge, Institute of Environmental Engineering \& Management, Mehran University of Engineering \& Technology, Jamshoro, Pakistan, for providing the support required in this study.

\section{REFERENCES}

Guimaraes, J.R., Guadagnini, R.A., Franco, R.M.B., and Dos, S.L.U., "Inactivation of Clostridium Perfringens, Total Coliforms, and Escherichia Coli by $\mathrm{UV} / \mathrm{H}_{2} \mathrm{O}_{2}$ in Wastewater Treatment Plant Effluent", Journal of Advanced Oxidation Technologies, Volume 19, No. 1, pp. 93-97, 2016.

Igoud, S., Souahi, F., and Chitour, C.E., "Solar Wastewater Treatment (SOWAT) and Reuse for Agricultural Irrigation", Irrigation and Drainage, Volume 66, No. 5, pp. $750-757,2017$.

Castro-Rios, K., Corpas, E.J., Cardenas, V., and Taborda, G., "Inactivation Efficiency of Total Coliforms and Escherichia Coli in Doped Natural water by Heterogeneous Fenton Effect of Process Factors", Journal of materials and Environmental Sciences, Volume 8, No. 1, pp. 364-369, 2017.

Hurdey, S.E., "Chlorination Disinfection by Products Public Health Risk Tradeoffs and Me", Water Research, Volume 43, No. 8, pp. 2057-2092, 2009.

Bach, L., Garbelini, E.R., Stets, S., Peralta- Zamora, P., and Emmel, A., "Experimental Design as a Tool for Studying Trihalomethanes Formation Parameters during Water Chlorination", Microchemical Journal, Volume 123, pp. 252-258, 2015.

[6] Awaleh, M.O., and Soubaneh, Y.D., "Waste Water Treatment in Chemical Industries: The Concept and Current Technologies", Hydrology Current Research, Volume 5, No. 1, pp. 01-12, 2014.

Rijal, G., and Fujioka, R., "Synergistic Effect of Solar Radiation and Solar Heating to Disinfect Drinking Water Sources", Water Science Technology, Volume 43, No. 12, pp. 155-162, 2001.
Burch, J., and Thomas, K., "Water Disinfection for Developing Countries and Potential for Solar Thermal Pasteurization", Solar Energy, Volume 64, No. 1, pp. 87-97, 1998.

[9] Acra, A., Raffoul, Z., and Karahagopian, Y., "Solar Disinfection of Drinking Water and Oral Rehydration Solutions: Guidelines for Household Application in Developing Countries", Department of Environmental Health, Beirut, 1984.

[10] Rojko, C., "Solar Disinfection of Drinking Water", Thesis, Faculty of Worcester Polytechnic Institute, May, 2003.

[11] Conroy, R., Elmore-Meegan, M., Joyce, T., McGuigan, K., and Barnes, J., "Solar Disinfection of Drinking Water and Diarrhoea in Maasai Children a Controlled Field Trial”, Lancet, Volume 348, pp. 1695-1697, 1996.

[12] Kehoe, S., Joyce, T., Ibrahim, P., Gillespie, J., Shahar, R., and McGuigan, K., "Effect of Agitation, Turbidity, Aluminum Foil Reflectors and Container Volume on the Inactivation Efficiency of Batch-Process Solar Disinfectors", Water Research, Volume 35, No. 4, pp. 1061-1065, 2001

[13] Ellis, K., "Water Disinfection: A Review with Some Consideration of the Requirements of the Third World", Environmental Science and Technology, Volume 20, No. 5-6, pp. 341-407, 1991.

[14] McGuigan, K., Joyce, T., and Conroy, R., "Solar Disinfection Use of Sunlight to Decontaminate Drinking Water in Developing Countries", Medical Microbiology, Volume 48, pp. 785-787, 1999.

[15] Fujioka, R., and Siwak, E., "The Cidal Effect of Sunlight on Alternative Microbial Indicators of Water Quality", Proceedings of AWWA Water Quality Technology Conference, Houston, TX, 1985.

[16] Conroy, R., Elmore-Meegan, M.Z., Joyce, T., McGuigan, K., and Barnes, J., "Solar Disinfection of Drinking Water Protects Against Cholera in Children under 6 Years of Age”, Arch Dis Child, Volume 85, No. 4, pp. 293-295, 2001. 
[17] Wegelin, M., Canonica, S., Mechsner, K., Fleischmann, T., Pesaro, F., and Metzler, A., "Solar Water Disinfection Scope of the Process and Analysis of Radiation Experiments", Water Supply Resource TechnologyAQUA, Volume 43, No. 3, pp. 154-169, 1994.

[18] Mahvi, A.H., "Feasibility of Solar Energy in Disinfection of Drinking Water in Iran”, American-Eurasian Journal Agricultural and Environmental Sciences, Volume 2, No. 4, pp.407-410, 2007.

[19] Ndabigrgesere, A., Narasiah, K.S., and Talbot, B.G., "Active Agents and Mechanism of Coagulation of Turbid Waters Using MoringaOleifera", Water Resources, Volume 29, No. 2, pp. 703-710, 1995.

[20] Elkarmi, A., Abu-Elteen, K., and Al-Karmi, A., "Disinfecting Contaminated Water with Natural Solar Radiation Utilizing a Disinfection Solar Reactor in a Semi-Arid Region”, Jordan Journal of Biological Science, Volume 1, No. 2, pp. 47-53, 2008.

[21] Gomez Couso, H., Fontan Sainz, M., Sichel, C., Fernandez Ibaeez, P., and Ares Mazas, E., "Efficiency of Solar Water Disinfection Method in Turbid Waters Experimentally Contaminated with Cryptosporidium Parvum Oocysts Under Real Field Conditions", Tropical Medicine and International Health, Volume 14, No. 6, pp. 620-627, 2009.

[22] Jamal, W., and Siddiqui, M.A., "Effect of Water Depth and Still Orientation on Productivity for Passive Solar Distillation”, International Journal of Engineering Resources and Application, Volume 2, No. 2, pp. 1659-1665, 2012.
[23] Meierhofer, R., and Landolt, G., "Factors Supporting the Sustained use of Solar Water DisinfectionExperiences from a Global Promotion and Dissemination Programme", Desalination, Volume 248, No. 1, pp. 144-151, 2009.

[24] Alejandra M.D, Ma, Alarcon-Herrera T., Ignacio R. Domýnguez M., Gonzalez-Herrera A., "Efficiency in the Disinfection of Water for Human Consumption in Rural Communities Using Solar Radiation", Solar Energy, Volume 78, No.1, pp 31-40, 2005.

[25] Dessie, A., Alemayehu, E., Mekonen, S., Legesse, W., Kloos, H., and Ambelu, A., "Solar Disinfection an Approach for Low Cost Household Water Treatment Technology in South Western Ethiopia", Environmental Health Sciences \& Engineering, Volume 12, No. 25, pp. 1-6, 2014.

[26] Sommer, B., Marino, A., Solarte, Y., Salas, M., Dierolf, C., Valiente, C., Mora, D., Rechsteiner, R., Setter, P., and Wirojanagud, W., "SODIS- An Emerging Water Treatment Process", Water Supply Research and Technology-Aqua, Volume 46, No. 3, pp. 127-137, 1997.

[27] Ambelu, A., and Faris, K., "Storage and Local Media Filters in Contaminant Removal", Proceedings of $25^{\text {th }}$ WEDC Conference Addis Ababa, Ethiopia, WEDC Loughborough, pp. 273-275, 1999.

[28] Yarahmadi, M., Hossieni, M., Bina, B., Mahmoudian, M., Naimabadie, A., and Shahsavani, A., "Application of MoringaOleifera Seed Extract and Poly Aluminium Chloride in Water Treatment", World Applied Science Journal, Volume 7, No. 8, pp. 962-967, 2009. 